\title{
The Cultural View of the Luo People of Western (Kenya) on Widow Care and the Biblical Approach
}

\author{
Miruka Philip ${ }^{1, *}$, Nathan Joshua ${ }^{2}$, Jack Obongo ${ }^{3}$ \\ ${ }^{1}$ Department of Theology, Faculty of Arts and Science, Great Lakes University of Kisumu,(GLUK), Kenya \\ ${ }^{2}$ Department of Biblical Studies, African International University, Kenya \\ ${ }^{3}$ Department of Theology/Sociology, Faculty of Arts and Science, Great Lakes University of Kisumu,(GLUK), Kenya
}

Copyright $(\subset 2015$ Horizon Research Publishing All rights reserved.

\begin{abstract}
Widow Care plays a central role in the luo culture, this is because marriage was treated with a lot of respect and therefore whenever one's spouse died then the cultural norms and procedures of widow care was launched. If the woman whose husband has died was married legally according to the Luo Cultural norms whereby the brideprice was paid to her parents then, she is accepted within the family of the deceased husband and if she was not, then she might be forced to return to her parent's home. Some of these cultural norms have been misused in the past years whereby the context of widow care has been misunderstood. In several occasions widows have been exploited and their lives threatened by deadly diseases such as HIV infections in the name of Widow Care. Wife Inheritance which was a custom practiced by the luo people of western Kenya in the name of widow care dictates that "if a man dies, one of his brothers or close relatives inherits his widow and must meet all of her marital requirements. It is for these reasons why the study was conducted to help bring proper understanding of Widow Care among the luo people. Widows are also confronted with various challenges which include: Burden of raising their children, economic exploitation, and denial of rights to remarry men of their choice, fear of excommunication and lack of mutual respect. The study conducted among the evangelical five churches and its environs in central lake region-Kisumu County which revealed that many Luo Widows are still in a state of dilemma as to whether to continue with the traditional practice of widow Care or to abandon it completely. The bible clearly outlines how widow Care should be practiced.
\end{abstract}

Keywords Cultural, Mutual, Dilemma, Launched

\section{Introduction}

Luo culture is patrilineal in the sense that life is centered on the male lineage. Upon marriage, a woman moves to where her husband's family is located. Among the Luo people inheritance and residence are also centered on the male lineage and so men are the major decision makers and controllers of wealth and power. Therefore, upon marriage husbands and families give bride wealth for the reproductive capabilities of women. This makes marriage to be considered actualized when the woman relocates to a geographical place of residence which is agreeable to the man. Ayayo asserts, "it is therefore a common saying in the luo [sic] that marriages is not a mutual affair: the man marries the woman and the woman gets married to the man in reference to the idea of relocation of the woman"1. Virtually all power lies in the hands of the elderly males. This confirms the power of culture in terms of marriage among the Luo people. In circumstances when death of a spouse occurs, an investigation is launched to confirm if the two were indeed properly married. The use of bride wealth in marriage is a common practice in the Luo community. However, it is not only among the Luo where levirate was practiced but it was also found in other communities in Africa. Ojwang affirms, "It is noteworthy that most patrilineal communities in Africa practice or used to practice levirate"2. These communities include: Igbo people of southeastern Nigeria, Somali communities, Maragoli of western Kenya and Dinka of south Sudan. The social aspect of the cultural practice of widow is approached from the biblical point of view and this does not mean that the present stand of the old tradition of luo practice should be abolished. The purpose is however to call the luo women to be autonomous in terms of making constructive decision for their well-being in the community. Both the Old Testament and the New Testament confirms how widow care can be practiced in line with the scripture.

\section{Rationale of the Study}

Widowhood practices are closely tied to cultural and traditional beliefs about death, ghosts, inheritance, feminine roles, family structure and family relationship. The overpowering belief in the ability of the ghost of a dead 
person to come back to dispute and haunt all kinds of things and relatives has reinforced and perpetuated the age-old practices of widowhood in western Kenya. Sossou argues, "The belief that death brings corruption and the dead still have contact with the living, especially their closest partners in life, is one of the reasons used for subjecting widows to inhuman and humiliating customary practices"3. The satisfactory completion of these ceremonies, rituals and practices is therefore believed to help restore the balance and security which death had sought to overthrow. The people due to superstitious beliefs, rationalize these practices with the argument that they perform important functions such as giving the widows protection from their powerful deceased husband with the intention of exploiting them and bringing down their self-esteem in the society. Ntozi asserts, "Through ter (culturally sanctioned remarriage), as a Luo cultural practice, a male relative of the deceased takes over the guardianship of the deceased's family including the wife, so that the deceased's inherited property stays in the family"4 The study therefore is not to abolish the present and the old tradition of the luo-practice of widow care but to identify some of the amicable ways by which widow care can be practiced without interfering with the well-being and family structure of the widow.

\section{Study Objectives}

To find out the Luo Cultural practices on widow care and establish the biblical teachings on the practice.

\section{Methodology}

Study population

The five (5) evangelical churches studied had a population of approximately five hundred (500) members, the widows from three widows welfare Association in the area were sixty (70) and the widows from the surrounding vicinity were twenty (20) whereas the traditional elders who were not attached to any church were fifteen (15). The respondents involved in the study were traditional luo-widows who strongly support the cultural practice of widow care, widows and elders within the church and traditional luo-elders who support the cultural practice and the five medical-health workers (officers) from the region.

\section{Study Area}

The study was conducted in central lake region in Kisumu County, this is one of the areas where the practice is predominant and that many of the evangelical churches and a number of widows associations are available. The region consists of over twenty churches and ten (10) widow's welfare Association and few health-care centres and clinics.

\section{Research Design}

The research design employed in this study was a descriptive survey. Kombo affirms that, "research design is an arrangement or conditions for collection and analysis of data in a manner that aims to combine relevance with the purpose". The survey was used to collect information from the respondents by interviewing through structured questionnaires, oral interviews and through unstructured questionnaires, observations and focused group discussions. The information were collected from the respondents on the challenges facing widows, negative and positive effects of the cultural practice of widow care, the value of the practice to the luo-community, church involvement in supporting widows, church response to the cultural practice and how best the practice can done without interfering with the widows.

\section{Sampling Techniques}

The purposive sampling was used because the study targeted specific group of people such as the traditional and Christian luo-widows, elders in the church and traditional luo-elders and Pastors from the church. The widows were purposively interviewed because they were directly affected. The survey showed that there were a total of fifty (50) Christian widows in the five (5) studied evangelical churches, this is because each of the five churches had at least ten (10). The traditional elders and widows were purposively interviewed because it was believed that they have an in-depth understanding of the luo-cultural practice of widow care. The Christian elders were interviewed for they had the concept of what the bible say about the practice and finally the Pastor were purposively sample (5) because they fully understand the bible teachings on widow care. Out of fifty (50) Christian widows only twenty-five (25) were sampled for interview this equivalent to fifty percent $(50 \%)$. The widows in the welfare Association were seventy (70) out of this forty (40) were sampled for interview and this was equivalent to fifty-seven percent $(57 \%)$. The traditional widows were twenty (20) all of them were interviewed this total to one-hundred percent $(100 \%)$. Out of fifty elders in the church only twenty-five (25) were sampled this is equivalent to fifty percent $(50 \%)$. Fifteen traditional elders (15) were all sampled for the interview this was converted to a hundred percent $(100 \%)$. Five (5) medical practitioners from the heath-care centres and clinics were sampled for interview because they considered instrumental in advising the widows on how to practice good sexual behavior when they are confronted by beliefs and rituals that pertains to the cultural practice of widow care. The overall sample size of the total respondents sampled for the interview were one-hundred and twenty (125).

\section{Data Collection and Analysis}

The study developed from the population from three widow's welfare association, medical-health workers (officers), traditional widows, Christian widows and elders within the church, traditional elders who strongly uphold the cultural practice of widow care. The older traditional widows interviewed were averaging 60 years (range 58-70 yrs). They 
were twenty (20) and a hundred percent $(100 \%)$ interviewed were upholding the cultural practice of widow care. The luo-traditional elders interviewed were fifteen averaging

67years (range 66-75 yrs) and they strongly support the practice. The Christian widows interviewed were averaging

63 yrs (range $62-70$ yrs). Seventy-five percent $(75 \%)$ of them who were interviewed opposed the practice and the rest twenty-five percent of them $(25 \%)$ were in the middle ground that is standing in between the cultural practice and Christianity. Widows from the welfare Association selected for interview were also averaging 45 yrs (range 44-60 years) they also opposed to practice saying that it is a life-threatening practice especially in this moment of HIV epidemic. Elders in the church interviewed were averaging 68 yrs (range 68-75 yrs) they reiterated that the bad part of the practice should be abolished and good side embraced by the luo-community. The health-workers interviewed were averaging 35 yrs (35-55 yrs) their response was that the practice is good but the ritual part of it is that which cause problems and advice the victims (widows) should practice protected sex by use of condoms if they should. The Pastors interviewed were averaging $30 \mathrm{yrs}$ (range 30-60 yrs) they opposed the ritual part of the practice and said that more biblical teachings should encouraged in the churches to create awareness of effects of the practice.

Both secondary and primary sources were used to collect the data. The respondents were selected for interview where purposive sampling was used of which a group of the respondents believed to be reliable for the study were purposively targeted from the five evangelical churches in the central lake Region, Kisumu County. Secondary sources included the published and the unpublished materials which include: books, newspapers, articles, journals and internet. Primary sources were obtained through structured questionnaires, oral interviews and observations. The collected data was then analyzed using qualitative methods where the research seeks to describe and analyze the culture and behavior of the respondent studied.

\section{Tools used for data collection}

The tools used for collecting data included an interview scheduled for the targeted group of respondents believed to give the relevant information which corresponds to the rationale of the study. Pictures and video were used to recapture some of the important information which may have forgotten. Mobile phone recorder was used to record answers given by the respondents. Note book diary was used to put down notes and also significant observations were maintained throughout the entire data collection process. The tools were important for they helped in the documentation of the accurate information.

\section{Results}

The study revealed that luo widows face various challenges. These include: burden of raising children, economic exploitation, and denial of rights to remarry men of their choice, fear of excommunication and Lack of mutual respect. The traditional luo-widows who uphold cultural practice of widow care their lives are threatened by being vulnerable to contracting HIV Virus especially when cultural-sanctioned remarriage is practiced through rituals in unprotected sexual behavior by failure to use condoms. The study revealed that more awareness should be done by the health-workers to help the widows on how to practice safe and protected sex by the use of condoms. The church ministers should to teach the members on what the bible say about widow care. The study revealed that widows should be encouraged to join widow's welfare Association which can help them to secure income that can help them to become autonomous so that they don't become a burden to the church and the community. The challenges facing the church are: Rapid numerical growth, inequalities in distribution of resources, ethnic friction, administrative weakness and poor strategies in mobilizing the resources. The study showed that most of the traditional- Luo widows still uphold cultural practice of widow care through wife-inheritance. The luo-cultural practice of widow care was done as an expression of love to the deceased husband family and protection to the widow. Furthermore, the study revealed that Widow Care was practiced in the early church in accordance to the biblical principles without involving the unhealthy cultural practice of widow care.

\section{Discussion}

Widows are confronted with various changes which must be dealt with urgently, for example the practice of widow-inheritance in the name of widow care. People need to be sensitized about the dangers of such practice. On the other hand the Study revealed that the practice of widow care is healthy and good if practiced in accordance with the Biblical principles. The cultural practices associated with widowhood such as ritual-cleansing should not be incorporated in the practice, for it will facilitate the high rate of HIV/AIDS infections especially to the widowed women. The presence of HIV/AIDS Scourge is a serious challenge today not only to the institution of lako, but humanity in general. To institution, it becomes imperative that the vulgar sense of guardianship be discouraged or abandoned all together. However, for the young and apparently energetic people, they should undergo medical examinations to ascertain their status before the rite and maintain moral behavior within the institution. The study revealed that luo culture through the institution of lako was intended to discourage the possibility of seeing a member of the deceased family suffer without someone extending a helping hand. This would encourage mutual relationship in the society. The Luo rules of conduct which advocate for love to ones kin or stranger brings about the value of treating human life with the highest respect and dignity by considering the killing of a human being a grave offence. This creates a sense 
of honor of the sanctity of life. The purpose of caring for the widow was to maintain the cultural norms that governed the luo community. The luo cultural practice of widow care cannot be totally abolished because if it is done away with then, the culture will be lost but what seems to be vital is to make a number of adjustments in order to discourage some of the abuses that are becoming prevalent in the cultural practice, with a view of making it adjustable to some of the challenges of our time for example HIV/AIDS epidemic in this generation. The empowering of widows will make them to be relieve the church and entire society from burden for they will be able generate income for self-sustainability. The widows will also be able to be autonomous in making concrete decisions without being undermined.

\section{Literature Review}

\section{Luo Cultural View on Widow Care}

In the Luo community the bride wealth was imperative for the legitimacy of marriage to be recognized. Although the 'come we stay' (cohabitation), phenomenon which currently threatens the payment of bride wealth and so undermines the stability of marriages, it is generally believed that a commitment to paying bride wealth is an indication of an equal commitment to the sustainability of the marriage. The bride wealth serves various purposes as Potash points out:"It is husband's gratitude for a good wife, his appreciation of the wife's dignity and worth, the wife's assurance of her husband's confined recognition and respect and also helps to control both the number of women available for marriage (since polygamy is allowed by the Luo culture), to the same man and the rate of divorce is high", the author has left out the issue of widows in relation to their care.

This makes marriage to be recognized by both the families of the bride and the groom, more specifically if the man has paid the bride wealth. Therefore, in a situation where a husband dies before paying bride wealth for his wife, the brother's in-law of the wife or other relatives of the deceased husband must pay the bride wealth or the woman may choose to go back to her parents. If it is the wife who has died, then the husband must pay the bride wealth before he is allowed to bury her as his wife. Payment of the bride wealth by a husband is a demonstration that a man has come of age and that he has not only the capability to support himself and his wife but also has attained the level of commitment required to sustain the marriage. The acceptance of the bride wealth simply signifies the family's recognition, support and blessing of the union which actually seals marriage in life and death. Ndizi points out:

Once it is proved that marriage was properly consummated the widow acquires permanent acceptance in the home and if it is the man who survives then he is now allowed to undertake the widowhood rights. If it is the woman who survives, she is now in position to find a relative to her dead husband, who will perform various duties for the deceased husband. This is in preparation to go through cultural rights associated with widowhood ${ }^{7}$

Luo social structure defines gender division of roles and responsibilities in the family context. This is because certain duties such as constructing houses was to be undertaken by a man, while duties such as cooking for the family ought to be done by a woman. These gender roles changes when a woman is widowed for circumstances will demand that she take charge of her deceased husband's responsibilities such as educating her children, providing food for them and many others. Although Luo widows maintain a high degree of autonomy and have a say in the choice of their deceased husbands' homes instead of relocating to the residence of their inheritors, the widows have no domestic responsibilities towards the inheritor. However the inheritor may help with ploughing, paying school fees for the children or building a house for the widow which is a non-formal duty depending on the relationship between the widow and the inheritor. The inheritor must be the brother in-law who takes up the roles of the deceased husband who is actually referred to as Jalako or Jater. This arrangement is cohabitation of a widow with her brother-in-law in which the brother-in-law relates to the widow as a substitute for her deceased husband. Jalako is a brother-in-law 'yuoro' of the widow. He can be either the brother of the deceased or a paternal first cousin or a clan cousin. All these would generally be referred to as "brother in-law". In this context brother-in-law would have a wider in meaning than its usual narrow meaning in English. For instance, in the cultural setting there are no cousins, but instead those referred to as 'cousins' in English are referred to as 'brothers or sisters'. The Luo concept of brother is well-outlined by Wilson in reference to levirate when he states:

The levier, JATER, is usually a full brother, half-brother or close agnatic kinsman who stands to the dead man as a brother. Occasionally a JADAK or servant, who is well known to the family of the dead, may be chosen by the widow. Her preference is always respected in this regard. She may choose anyone within the LIMBAMBA of her husband without opposition ${ }^{8}$.

Lako is a means by which the Luo people actually attempt to cope up with death and its adverse socio-economic and psychological implications in order to fill the vacuum or gap created by the deceased husband. This was being done to help create or maintain social normalcy as much as possible. This was therefore a means of evaluating the disruptive implications or consequences of death. It also ensures that there is a continued family stability by providing for the missed rules and responsibilities of the dead husband. However, the practice of lako or ter is indeed very central to the luo culture. It is also a taboo to violate or go against it. Its violation is believed to bring serious misfortune such as chira. Therefore, to be able to really understand the institution of lako one is required to appreciate the Luo concept of marriage and death. This is because it's through Luo marriage rites that the adult world begins, is controlled, nurtured and at the same time lived.

Marriage is the central institution that actually sets the 
tone for the entire Luo society. Therefore, without marriage the Luo people could be without roots, stability and responsibility. This is why marriage is of great concern for the Luo community than anything else. It should be clearly understood that to the Luo culture, marriage is intended to be an everlasting contract whose purpose and function extends beyond the physical death of one or both of the spouses. "To the luo, the western or Christian marriage vow of fidelity and loyalty by the spouses to each other, "till death do us a part'(Matt.19:6, 1Cor.7:8-9) is a hollow slogan". This is because to the Luo people, physical death does not end one's life and so human life is a social reality which has its meaning and value only in the context of a social network of rights and duties. Kirwen also points out:"For the Luo's [sic] a person physically dead is still considered alive, present and capable of influencing the living. These relationships are seen to continue on intact through the barriers of physical death" 9 .

The above position has been succinctly and forcefully explained by Okotp'Bitek who is one of the great African conceptual analysts when he said, 'Man cannot and must not be free. 'Son', 'Mother', 'daughter', 'Uncle', 'grandmother', 'wife', 'Medicine-man', and many other such terms are the stamps of man's freedom. It is by such complex terms that he is defined and identified" ${ }^{10}$. All the terms above imply duties, rights and privileges that one owes and is owed in society. For the society comprise of two parties, that is, the visible and invisible members. This is because in African belief even death does not free a person. In other words, the above relationships do not end with death for one does not cease to be a mother, father, brother or sister by death. These are everlasting relationships once acquired and so are the responsibilities that they entail.

To the Luo, life is a social reality which implies corporate responsibility. Therefore, everyone has a duty towards ensuring the continuity of human life which includes the family lineage and the human race in general. The custom for the widows must therefore be seen as a temporal adjustment in marriage of the deceased brother to make sure that his family achieves its goals as if he were alive. Moreover, if one refuses to care for a brother's wife, it shows that he causes the deceased to put evil eye on someone and bewitch him by seeing how the inheritor treats his wife and family unjustly. Therefore, the Luo institution of lako is actually based on the fundamental principles of love and respect towards one's kin. This principle makes the basis for the presupposition of mutual responsibility and the virtues of empathy and sympathy. The principle of love continues beyond the grave. Since physical death of a woman's husband brings loss in the family, the bereaved wife and children experience loss or lack which in most cases brings suffering to the family of the deceased. The Luo culture through the institution of lako was intended to provide a 'surrogate' or a 'substitute' for the deceased to carry on with the roles and duties he used to perform. The culture was also intended to discourage the possibility of seeing a member of the deceased family suffer without someone extending a helping hand. And so, if a man dies and leaves behind a wife and children, then the brothers of the deceased must ensure that they are well taken care of. The most important thing in the institution of lako is not the sexual intercourse with the widow, but to take good care of the wife, children and property (wealth), so that the family of the deceased prospers and the children do not suffer.

Consequently, the community within which the widow lives can help her to overcome much of her grief. For example, in most cases acceptance of the widow after the death of her husband entirely depends on her cooperation with regard to the dictates of the cultural rights of widowhood. In addition, the widow's adjustment to her new status of losing a husband also depends on the support she gets from the family of her deceased husband. The widow's attitude of widowhood plays a very important role, for if a widow possesses adequate material resources from relatives and friends then this can adequately reduce her vulnerability to exploitation and being undermined.

\section{Purposes of Caring for the Widows}

There are several purposes why the Luo people considered it imperative to care for the widows. The first purpose was for the expression of love and respect. The Luo people considered that once a woman lost her husband then the community was to express love and respect to her. This was to practically shown by giving her support inform of food, school fees for the children and even providing shelter for her. This was being done to enable the widow to continue with her normal life even after the demise of her husband. Odaga argues, "The luo have 14 rules of conduct, one of which is love your kin or stranger, be it a person or ghost. Due to this principle of love, the luo treat human life with the highest respect and dignity"11. Subsequently, even the killing of a human being was considered a grave offence which automatically led to social and psychological isolation. In matters of self-defense, killing of a human being must be virtually cleansed. However, in the Luo culture love of a fellow human being, especially a member of one's family, which forms the basis of mutual responsibility, goes beyond physical life. The sense of mutual responsibility was founded on the feelings of empathy and sympathy since the Luo seem to realize that people encounter problems at different times in life, more so that of losing a husband; and there is none who is immune to problems. So anyone who suffers needs help from the rest of the community and this realization is actually expressed in various Luo sayings, one of which is, "Erolaki tar inyiero!" which is translated as "Your teeth are white; you are ever laughing!" This is said as a mockery to a person who seems to have no compassion for others; but no one can escape the ups and downs of life. On the same issue, Odaga further explained, "Every dog has its day" (Ibid,1994). Therefore, love expression becomes an important element in caring for the widows among the Luo.

Secondly, Luo purpose for caring for the widow was to maintain the cultural norms that governed the luo community. This was to make sure that all members complied to the regulations and rules set by society in regard to the care of 
widows. No one was expected to go against these norms or violate them. Kirwen asserts, "a rejection of the levirate as a cultural institution involves, in fact a rejection of African marriage systems entwined with a patrilineal corporate kin-group since the two are fundamentally related" (Ibid, 1979). This is because upon the death of a husband his brother takes up the roles and responsibilities of the deceased home including the wife and the children. That is to say, he assumes the home of the deceased. Therefore, levirate is a means by which the Luo people attempt to cope with death and its adverse socio-economic and psychological implications, filling the gaps created by death of a husband in order to help maintain the social normalcy as much as possible.

Thirdly, the care for a widow in the Luo cultural context was seen as a way of giving protection to the family of the deceased husband where the inheritor was to be the brother or cousin of the deceased husband to enable the family to continue with the normal life. Oruka explains that, "The man is a protector not just of the wife; he is in the first place the protector of the children and home of the deceased. This is why it is important that the function be performed by a relative and not a stranger" ${ }^{\prime \prime}$. The brother being the inheritor of the deceased wife has some limitation for he has no full control over the wealth of the deceased. The brothers-in-law were not to allow the guardian, be it one of the deceased's brothers to exploit or oppress the immediate family of the deceased brother. Consequently, he was not allowed to perform only the cleansing rite or sexual duty, but was required to be committed to the care of the family of the deceased husband. Finally, the purpose for caring of the widow was to ensure that there was continuity in the family of the deceased. For instance if the deceased had left the children while young, then they were to be supported by giving them food, shelter and at the same time take them to school so that they could become self-reliant and continue with the lineage of their father. The Luo customs of caring for the widows must actually be seen as a temporary adjustment in the marriage of a deceased brother to ensure that his family achieves its goals as if he was live to do them himself.

\section{Biblical view on widow care}

\section{Timothy 5:1-10}

Timothy was a young man from the city of Lystra, which was located in what is now southern Turkey. Timothy was Paul's beloved companion and co-worker (Acts 16:1-4). Timothy became Paul's closest disciple; Paul called him his true son in faith (1 Tim.1:2). Most Bible scholars believe that Paul wrote his two letters to Timothy after the events described in the book of Acts had taken place. These scholars believe that after spending two years under house arrest, Paul was then released and for one or two years continued his preaching and traveling. He could have written these letters to Timothy during that period. Paul was motivated to write this letter because he realized he was getting to be an old man and therefore he needed to pass on his apostolic authority to some younger leaders such as Timothy and Titus. However, even before writing this letter, Paul had already appointed Timothy to be the leader of the church in Ephesus(1 Tim.1:3). Paul therefore wrote this first letter to encourage him and instruct in his duties that is why from the Paul wrote this letter to the present, the letter has been very productive in the church leaders and those under them.

Given the preceding context in ( I Tim.4:14), "older man" may refer specifically refer to an elder because of the use of kinship terms for officers in the church accords with the description of Gods household in terms of family. This means that it refers female elders who hold a special office of older widows devoted to prayer just as applied to male elders. Keener asserts, "It is also possible that 1 Tim.5:1-2 is a more general of which widows and elders as church leaders represent specialized examples" ${ }^{, 13}$. In 1Tim.5:1-2 Paul gives Timothy many instructions on how to deal with various groups in the church. He reiterates that it is the responsibility of overseers (elders) and Pastors to reprove sin in the church and to discipline church members. However, it is never suitable to harshly rebuke an older person. Rather, the pastor should treat older people with the respect he would show to his own parents.

Verse 3. "Give proper recognition to those widows who are really in need" Paul meant not only those widows bereaved of husband but also both committed to the church's ministry of prayer and experiencing the stereotypical Old Testament plight of widows are the ones who needed to be honored by the church. Hale affirms, "Caring for widows is a very important Christian duty. Many widows have no way to support themselves. If a widow has no family members who can take of her, then the church must take responsibility for her welfare"14. When Paul says here to give widows proper recognition, he means that the church should care for widows and meet all their legitimate needs but the church only needs to care for those widows who are really in need. 1 Tim 5:4

"But if a widow has children or grandchildren these should learn first of all to put their religion into practice by caring for their own family and so repaying their parents and grandparents". On this keener affirms, "Adult children or other close relatives were expected to care for the destitute widows who had no opportunity to earn wages in the ancient society. It was believed that one this care to ones parents for their support during youth" (Ibid, 1993). If the children play their role in taking care of their parents then there is possibility that those widows who conform to the bad side of cultural practice of widow care are going to have affirmed stand by not giving in to such.

Paul in 1Timothy 5:5 "The widow who is really in need and left all alone puts her hope in God and continues night and day to pray and to ask God for help". The Jewish ideal for older widows received support from family or distributors of charity but the only contribution to society was prayer. This is probably unrelated to Roman image of vestal virgin's prayers supporting in Rome, although that image shows the ease with the idea could have been grasped 
even in pagan culture. Hale affirms, "For a widow to receive help from the church she must first be really in need and second, she must be one who puts her hope in God. She must be one who puts her hope in God and prays continually" (Ibid, 1996). The widow consistent pray will make God to provide her needs through human agents to accomplish his purpose. The widow in verse.6 Paul says that she is not legible to receive support from the church because she lives for pleasure which makes her spiritually dead and physically alive. Verse.7 "Give the people these instructions, too, so that no-one may be open to blame". This is a command Paul uses to remind Timothy to continue doing what they talked about before he left for Macedonia. Furthermore, Paul could not have delegated Timothy such a difficult task as the one in Ephesus unless he had confident that the young man could do it. Timothy was to give this instruction to widows and their families so that everyone may act properly and be blameless.

1 Timothy 5:8 "If anyone does not provide for his relatives, and especially for his immediate family, he has denied the faith and is worse than unbeliever". In this verse Paul teaches a spiritual principle that a Christian must provide materially to his own for failure to do so was to reject Christian faith and so one becomes worse than a believer. This kind of action would bring reproach on the family before the unbelievers and discredit the cause of Christ in Ephesians' Christian family. Verse.9 'No widow may be put on the list of widows unless she is over sixty, has been faithful to her husband and is well known for her good deeds such as bringing up children...". The emphasis of Paul is that there is a certain age limit that a woman may reach after the death of husband to qualify as a widow. The expression "Put on the list" was often used of official registrations for example troops and "sixty" was a Jewish figure for the beginning of old age (Lk.1:7).

New Testament states that as Jesus approaches the city of Nain, 'there was a dead man who was carried out, the only son of his mother and she was a widow and many people of the city were with her' $(\operatorname{Lk} 7: 12)$. The widow lived in a small town a few miles south of Nazareth in Galilee. Sometime before, she had lost her husband. It was a sad day for her because death had robbed her not only of the companionship of her husband and son but it also took away the last hope she had for any means of material support. "When the Lord saw, his heart went out to her and he said, "Don't cry." Then he went up and touched the coffin, and those carrying it stood still. He said, "Young men, I say to you, get up!" The dead man sat up and began to talk, and Jesus gave him back to his mother" (Lk7:13-15 NIV). Jesus did this because he was moved by the widow's plight and he raised her son from the dead so that he would continue to care for his widowed mother. Jesus' insight on the care of widows reveals his condemnation of those who take advantage of them. Another example of widow care explained in the New Testament is that of the Early Church especially in the Church at Jerusalem. Because the church at Jerusalem was growing rapidly, "There arose a murmuring of the Grecians against the Hebrews, because their widows were neglected in the ministration" (Acts 6:1ff). The "Hebrews" referred to are the Jewish people living in Palestine while "Grecians" (also called Hellenists) refers to Jewish people who had been actually dispersed to live outside Palestine. Perhaps those referred to in Acts 6 were the residents of the city or stayed in homes with other Christian families or were staying in various inns.

Apparently, the Hellenistic widows in the church did not receive the same care as those from Palestine and perhaps that was because the Hellenistic widows were not part of the Jewish community. Whatever the reason, the fact is that the apostles gathered the believers together and asked them to "find seven men of honest report, full of the Holy Spirit and wisdom" to care for the Hellenistic widows (Acts 6:3). The reason for the apostles to do this was so that fairness would be exercised in meeting each widow's need. The plan of the apostles pleased the Hellenistic believers and seven men were chosen. In another episode, in the city of Joppa also lived a kind and gracious believer and a widow named Tabitha (also called Dorcas). But she became sick and unfortunately died (Acts 9:36-37). Normally, it was not the Jewish custom to embalm the body but only to wash it for a time of viewing or mourning (vs.37). However, the believers in Joppa heard that Peter was in the nearby city of Lydda and so they sent for him obviously knowing that he had demonstrated the power of God through many previous miracles.

Peter 'raised Tabitha' because he had the great concern for the widows especially when he saw their mourning and keeping for their colleague. The broken-hearted widows of Joppa were comforted because the woman was so dear to them had been raised from the dead. The Early Church during the time of the apostles. In another New Testament text James defined the essence of true religion as demonstrating compassion to the poor and needy, specifically to the widow and the orphan by stating that, "Religion that God our father accepts as pure and faultless is this: to look after orphans and widows in their distress and to keep oneself from being polluted by the world" (James 1:27). The incidences indicate that widow care was necessary and important practice in the New Testament.

In the Old Testament we have various references to the levirate practice of the brother of a deceased man marrying his widow. The levirate marriage is the practice of a widow marrying the brother of her deceased husband (TAG, 1994). In Genesis 38:6-11 the father advised the son to take over the widow. In Deuteronomy 25:5-10 it was expected that the widow marry in the family and man who refused to marry the widow of his deceased brother was stigmatized, disgraced and spat on in contempt $(25: 7,10)$. In the book of Ruth levirate marriage was extended to an unnamed kinsman (Ruth 4:2-12), this practice continued among the Jews in the New Testament for the Sadducees questioned Jesus concerning a problem that would arise from the levirate marriage (Matt.22:23-32).

God's special compassion for widows is very evident throughout the Old Testament. There are strict warnings 
against anyone who attempts to abuse them as the scripture affirms, "Do not take advantage of a widow or an orphan. If you do and they cry to me, I will hear their cry" (Exo. 22:22). God also declares that he is their defender, he protects and cares for them (Deut. 10:18, Ps 68:5, 146:9). Malachi states that those who oppress widows do not fear Almighty God (Mal.3:5). God also declares that a widow and her children depend on him for sustenance (Jer. 49:11). Consequently, God says that his curse is upon those who mistreat widows and orphans (Deut. 27:19), but those who care for them are promised God's blessing (Jer. 7:5-7). The above scriptures confirm that widows should not be exploited but cared for.

\section{Biblical Principles to Guide the Christian Church in the Marriage of Widows}

First, whether the Christian widow marries or not, she is under obligation to live a life of purity and above reproach. Secondly, young widows should marry to avoid any temptation from Satan (1 Tim.5:11,15). Purity is of first importance. Fornication is completely forbidden. If a younger widow finds her sexual drives too strong, she has an obligation before God to marry rather than to fall into sin, if the lord leads her to a Christian husband. Thirdly, If older widows are unwilling to marry, they should be assisted by their children (1Tim. 5:4). Older widows, who lack material means to support themselves, should then be supported by their children. Fourthly, the church should assist the widows whose families cannot help them (1 Tim. 5:4, 16). It is up to the church to find best method of helping these widows. Fifthly, Christians must be taught to follow the scriptures rather than tradition especially when the traditions contradict the scripture. It is better to forget the traditions and ignore what people say and think for it is important to build our beliefs and solve our problems on the basis of Scripture, even if there is resistance from traditions and society. Finally, it is imperative to note that, we are at a cross roads for we have issues of traditional customs which are very strong. But what does the Bible teach? What the traditional customs say are not what the bible teaches. It is time for the church to teach that a widow has a right to marry and handle her family.

\section{Challenges Facing Luo widows}

Widowhood often changes the social and economic roles of women. In the household and community; its impact differs according to culture and religion within different communities. Widowhood affects the physical safety, identity and mobility of widows and their children. Widowhood also affects widows' access to basic goods and services which are necessary for their survival as well as their rights to inheritance. The report given by International Committee of the Red Cross (ICRC) on 6th November, 1999 shows that when widows lose their husbands they are often deprived of support from traditional sources which can cause economic hardship or deprivation. Furthermore, they often feel reluctant to talk about their loss because of fear of excommunication and other punishments. Widows' grieve and often bear the burden of raising their children in silence.
Therefore, those with dependent children often say that their main reason for going on with in life is the responsibility of raising their children.

The inheritors who become the guardian of the family after the death of the husbands actually becomes economic predators as argued by Ntozi that, "The women have no choice because those who say that they are giving guidance are also inheriting immediate property of the husband. So in fact that financial support they are giving is the real property which should have gone to the widow. What she lacks is the legal capacity to own that property" (Ibid 1994). Indeed it is true that instances of economic or material exploitation have been known to occur within the institution. They are unfortunate cases of abuse rather than the accurate observation of the custom.

The institution of lako is in principle an institution of care and not of exploitation of any kind. However, in the Luo cultural universe, it is never known of any case where widows fail to get a guardian on account of her poverty. In fact, it is considered a taboo for any widow not to have a guardian. Some widows have ignored the threat of taboo and do without guardians whenever there are good reasons to do so especially in case of inheritors who are economic predators. Additionally, Ojwang argues that the" Luo cultural universe of levirate marriage denies the widow the right to choose either to remarry or not. This is true because in the Luo culture, to choose to marry or not in itself does not arise. Not marrying and getting a child would be self-annihilation and hence an abdication of the sacred duty of partaking in and perpetuating life. It should therefore be noted that for the Luo, failing to perpetuate oneself by having children is a great misfortune" ${ }^{15}$.

Most of the challenges experienced by widows are concentrated in the rural area. Laurine also argues that, "Widows in rural luo community in Kenya are subjected to destructive rites due to their relative vulnerability, low literacy and lack of exposure. Many of them who have no source of income find it difficult to resist being inherited for fear of excommunication from their matrimonial homes without any entitlement to the estates of their deceased husbands ${ }^{13}$.The above statement is actually in sharp contrast to urban Luo women who are largely enlightened and therefore become independent without intimidation. Consequently, the report given by National AIDS and STD Control Program (NASCOP), points out:

There is evidence that most rural luo widows with secondary school education and economic stability ignore the cultural requirement of the guardian. On the other hand, widows with primary school education and no economic empowerment more readily submit to such cultural demands. Thus intervention through education has helped Luo widows to refrain from life-threatening widowhood rituals (NASCOP, 2005).

Furthermore, the luo widows face the challenge of becoming vulnerable of contracting HIV/AIDS especially among those who still cherish the practice of lako where sexual intercourse is given preference for ritual cleansing. 
This is retrogressive to the society. The rationale would show that the spread of HIV/AIDs is partly caused by sexual intercourse and therefore can be checked by good sexual moral behavior. For instance, if an infected person engages in risky sexual intercourse, be it within the institution of marriage or guardianship or outside them, then HIV/Aids disease is likely to be contracted. Prince asserts, "given the presence of HIV/AIDS, if a widow (Chi liel) cannot absolutely abstain from sexual intercourse, then it is even better if she has a guardian because this restricts her from sexual relations, otherwise, the possibility of her getting infected or re-infected are higher when she does not have a guardian than when she has one" ${ }^{16}$.

Some men have also entered the institution of lako not because they want to assist and care for the family, but only to perversely enjoy either the material benefits of the home or warmth of sparkling wives. These kinds of men are seen in widow's homes only during meal times or bed times. This however, becomes a real insult to the sacred institution. The absurdity of such kind of behavior should be seen in the light of the fact that the institution of lako in principle has become a burden in the sense that any man who is of good sense and good will would not impose himself on the widow. There have also been reported cases of evil brothers-in-law, fathers-in-law and mothers-in-law who plunder the wealth of the immediate family of the deceased, thereby subjecting the widow to undue material and psychological suffering. However, the widow should also develop a warm relationship between herself and her in-laws. In other words, there should be a family spirit. This calls for a spirit of mutual respect and care within the family. Other challenges include coping with pain of widowhood, loneliness, as well as social isolation.

\section{Challenges Facing the Church}

The church is faced with numerous challenges which have actually contributed to their failure in support to the widows. Some of these challenges are artificial in nature in the sense that they are contributed by the congregation and the church ministers as well. However, these challenges vary from one church to the other depending on the administrative functions and style of the church leadership. Such problems or challenges were also experienced by the Early Church during the apostolic age. Carter observes, "The apostolic church, like the church of every subsequent generation had its problems"17. The challenges faced by the churches include the following:

\section{Rapid numerical Church Growth}

In a situation whereby the church grows rapidly, it might sometimes be difficult for it to be able to identify and recognize the widows need and be able to identify the needy ones who need to be supported by the church. Such scenario was also experienced in the church of Jerusalem for there was rapid growth in size of the congregation which really contributed to the development of the problem recorded in Acts 6. Luke however, explains by stating that, "In those days when the number of disciples were increasing, the Grecians Jews among them complained against the Hebraic because their widows were being overlooked in the daily distribution of food"(Acts 6:1). Before he reported people were added to the church, he says the number was multiplied. When this happened, it then became difficult for the church to adequately meet the needs of the widows within the church and so made the Complaint to arise.

\section{Ethnic Friction}

Ethnic friction has also contributed to the failure of the church to support the needy widows in the church. This is so because in a church where different tribes come together to worship, there are possibilities that widows from the majority tribe in the church receive the support given by the church if any. But the minority of the widows might be sidelined on ethnic background. Concerning ethnic friction in the Early Church, Oruka affirms, "However, ethnic friction also played a part in the development of the problem in the church at Jerusalem ${ }^{12}$. The problem of ethnic friction is still evident in some congregations today as it was with the church at Jerusalem. Subsequently, he asserts, "Jealousies, ill feelings between the Hebrews and Grecians lurked in the background. The Hebraic Jewish believers considered themselves somewhat superior to others. Their place of birth was Palestine. Today the native born Israelites consider themselves recent immigrants to the county almost as second-class citizens. They continued to speak the mother tongue, Aramaic or Hebrew and remained in the Promised Land while others had migrated elsewhere before returning to the homeland.

Ethnic friction in the church is promoted by unsanctified human nature people consider the minority widows within the church which makes them experience a language barrier which then exposes them to be extra-sensitive regarding the issues related to widows and their welfare programs. Consequently, ethnicity can result because of different ideologies as far as widow's welfare about how to handle them more appropriately. Therefore, the churches which have allowed them to be absorbed in this kind of friction will face this kind of challenge. If appropriate measures are not taken to help deal with it, then it will eventually split the church and the church will not be able to support the needy widows'.

\section{Inequities in distribution of resources}

Distribution of resources equitably to the people becomes a challenge not only in the church but also in the entire globe, more so in the African countries. This trend has also entered the church especially in churches where funds are allocated specifically to meet the needs of the widows and other groups of people who needs church support. There are times when these funds are directed to do irrelevant functions which it was not intended to do. Sometimes these funds are squandered by the people concerned rather than using them for the welfare of the widows. In a church whereby the available funds or resources are not distributed equitably 
they are likely to meet the challenge of giving support to their widows within the church. Therefore, there should be financial equity and resources among the needy congregation. It is in relation to equitable distribution of resources that made Prince to argue that, "Distributing resources equitably means recognizing the fact that in Gods economy he equips some with more so that they can bless others who have less" ( Ibid 2004). So the socio-economic equity should be engrained into the church in order to overcome the challenge.

\section{Weakness in Church Administration}

Another contributing factor which has led the church to fail to support widows is administrative weakness in terms of handling resources for meeting widows' needs. Whenever there is weakness within the church administration on how it should function, then it will face the challenge of not only being unable to support the widows but also other needy people in the church, such as orphans and others. The church however should not only strive to meet the physical needs of the widows, but also their spiritual needs, which entails teaching them God's word and prayer so that their entire well-being is addressed. In the Early Church, there was administrative weakness as there also is in churches today. Carter asserts, "In moving toward a solution to the problem the apostles readily admit another cause. It was that of administrative weakness. To their credit they made no attempt to justify themselves or brand the critics as troublesome. Rather, somewhat apologetically they explain to the congregation that ministers of the church had their hands full in attending to the prayer and preaching" $\mathrm{Ibid}^{17}$.

They said that it would not be right for them to neglect the ministry of the word of God in order to wait on tables. This was because the apostles held that ministerial priorities must remain and so they gave themselves to prayer and teaching the word of God. The above are just some of the challenges facing the church which have contributed to the church's failure in supporting widows. Other challenges may include, financial constraints, irresponsibility of widows' relatives as highlighted in 1 Tim 5:4 and many others.

\section{Poor strategies in mobilizing resources}

The church has been reluctant in mobilizing the resources to support the widows within and out of the church. The church is supposed to imitate the example of the early church in Jerusalem whereby the were consistent in coming together for fellowship and by doing so, they were able to identify each person's need and make every effort to meet them. The book of Acts records, "All believers were together and had everything in common. Selling their possessions and goods, they gave to anyone as he had need"(Acts 2:45). The church actions played a great role not only in meeting the needs of the widows but also other church members who had the same needs for their daily living.

\section{Conclusions}

Widow Care among the Luo people in western Kenya was intended for the well-being of the widowed women; however its concept has been misunderstood by many. The positive side of widow care should be upheld by the Luo community by providing them with material support. The cultural practices meant to exploit and disregard the widow such as wife-inheritance should be discouraged. The church should take the responsibility to teach people about the biblical approach of widow Care. The families should be encouraged to take care of the widows within their families. The Church should initiate widow's welfare association where the widows can borrow money to begin some in-come generating programs for their self-sustenance. The church should device modernity's of creating a awareness on good sexual-behavior by the help of medical practitioners and health-workers if they have to comply to such practice. The luo elders who are experts in cultural norms should sensitized people on the positive side of widow care.

The widow must also recognize the power she carries within her. She must be aware of the fact that the woman was created as equal with man. She must begin to see herself as subject and not object by having self-worth. The widow must discard the policy of silence and voice out her feelings in whatever way she can. She must also dismantle images constructed around her and reveal her true self. By doing so, she will be able to carve out a space for herself by not allowing anyone tell her story but do it herself. This will make the widow to begin to see the sense of reality and take a step to face life confidently. The widow must fight sexual difference because it is a burden she has to discard if she is to make meaning in the society. For the young widow, she must aspire to acquire education to be able to adequately confront oppression. This will make them recognize that education for the woman does not end in the kitchen. Finally, she must stand against tradition that belittles her by courageously facing and dealing with culture, customs and norms that specify roles for her in the society. The study maintains that the custom is still the best alternative available to the Luo widow and for the care of the deceased home especially in the Luo culture. However, it recommends a number of adjustments to the practice to discourage some of the abuses that are becoming prevalent in it, with a view to making it more amendable to some of the challenges of our time for example HIV/AIDS epidemic in today's society.

\section{REFERENCES}

[1] Ayayo, A.1976. Traditional Ideology and Ethnics among the Southern Luo. New York: Africana Publishing Press.

[2] Ojwang, H.J. How the Luo Marriages Service Death"! In Gutema, Bekele and Daniel Smith eds.

[3] Sossou, Marshall.2002. The Politics of widowhood and Re-marriage among the Luo of Kenya. World Alive Publishers: Nairobi, Kenya.

[4] Ntozi, John. 1997. The Effects of Culture among the Luo of 
Kenya. Word Alive Publishers Nairobi, Kenya

[5] Kombo, D.K. 2006. Proposal and Thesis writing. An Introduction. Nairobi: Pauline's Publications Africa.

[6] Potash, B.ed. 1986Widows in African Societies: Choices and Constraints. California. Stanford University Press

[7] Ndizi, M. 2007. African Culture and the Christian Church. London: Geoffrey Chapman Publishers.

[8] Wilson. 1968. Luo Customary Law and Marriage laws customs .English Version. Nairobi: The Government Printer.

[9] Kirwen, C. Michael.1979.African Widows. An empirical study of the problems of adapting Western Christian teachings on marriage to the leviratic custom for the care of widows in Four rural African societies. Orbis Books, Mary knolls: New York.

[10] P'Bitek, O.1986. Artist: The Ruler. Nairobi: Heinemann Kenya Ltd.
[11] Odaga, A.B. 1994. Luo sayings. Kisumu: Lake Publishers and Enterprises Ltd.

[12] Oruka, H.O. 1994. "Wife inheritance is a bad name for this great practice". Sunday Nation (Nairobi) January 23.

[13] Keener. C.S. 1993. The Bible background Commentary. New Testament. Sri Lanka: New life literature.

[14] Hale, Thomas. 1996. The Applied New Testament Commentary. Kingsway Publications Ltd. East Bourne.

[15] Ojwang, H.J. How the Luo Marriages Service Death"! In Gutema, Bekele and Daniel Smith eds.

[16] Prince, Jeff. 2004. Luo Cultural Practices: Norms and Rules. Orbis Books, Mary knoll, New York.

[17] Carter, W.2004 The Wesleyan Bible Commentary. Grand Rapids, ML: William B. Eerdmans Publishing Company. 